\title{
SELECTION EFFECTS IN THE MARKET FOR INDIVIDUAL ANNUITIES: NEW EVIDENCE FROM THE UNITED KINGDOM
}

\author{
Amy Finkelstein \\ James Poterba
}

Working Paper 7168

http://www.nber.org/papers/w7168

\author{
NATIONAL BUREAU OF ECONOMIC RESEARCH \\ 1050 Massachusetts Avenue \\ Cambridge, MA 02138 \\ June 1999
}

We are grateful to the National Institute of Aging and the National Science Foundation for research support, and to Alex Bowen, Jeff Brown, Peter Diamond, Michael Orszag, and Peter Orszag for helpful suggestions. All opinions expressed are those of the authors and not those of the National Bureau of Economic Research.

(C) 1999 by Amy Finkelstein and James Poterba. All rights reserved. Short sections of text, not to exceed two paragraphs, may be quoted without explicit permission provided that full credit, including $\mathbb{C}$ notice, is given to the source. 
Selection Effects in the Market for Individual Annuities:

New Evidence from the United Kingdom

Amy Finkelstein and James Poterba

NBER Working Paper No. 7168

June 1999

JEL No. H5, J2, G1

\begin{abstract}
This paper presents new evidence on the importance of adverse selection in individual annuity markets. It focuses on the individual annuity market in the United Kingdom, which provides an excellent empirical setting for studying selection effects. In addition to a voluntary annuity market, the U.K. also has a compulsory annuity market in which individuals in some types of retirement plans are effectively required to purchase retirement annuities. Two empirical regularities support standard models of adverse selection. First, annuitants as a group are longer-lived than randomly selected individuals in the population at large. The expected present value of the annuity payout stream from a typical voluntary annuity is thirteen percent higher for a typical 65-year-old male voluntary annuitant than for a typical 65-year-old male in the U.K. population. This is simply the result of differential mortality between the annuitant population and the population at large. Selection effects are more pronounced in the voluntary than in the compulsory annuity market, but even compulsory annuitants are not a random sample from the U.K. population. In the compulsory annuity market, the cost of adverse selection is between one third and one half of that in the voluntary annuity market. Second, annuitants select across different types of annuity products with different payout profiles, even within the compulsory market. The expected present values of payouts from inflation-indexed annuities and from nominal escalating annuities are lower than those from nominal annuities. This is consistent with longer-lived individuals choosing annuity products with greater payouts in the distant future. We find some puzzling evidence, however, in the relative pricing of nominal escalating annuities and inflation-indexed annuities. In addition to providing evidence on adverse selection, the U.K. annuity market can also be used to study how the price of an insurance product is related to the quantity of insurance purchased. Prices per annuity unit are lower for larger annuity policies than for smaller policies. Some theoretical models of insurance demand, which suggest that poorer risks should purchase more insurance and do not consider the fixed costs of issuing annuity or insurance policies, are inconsistent with this result.
\end{abstract}

James Poterba

Department of Economics

MIT

E52-350

Cambridge, MA 02139-4307

and NBER

poterba@mit.edu
Amy Finkelstein

Department of Economics

MIT

Cambridge, MA 02139-4307

afinkels@nber.nber.org 
The market for individual annuities has recently attracted substantial attention as Social Security reform proposals have been advanced in various countries. Some proposals call for partly or fully replacing government-provided defined benefit, pay-as-you-go retirement systems with defined contribution systems in which individuals would accumulate assets in individual accounts. In such systems, one important question concerns the way in which individuals would draw down their asset balances during retirement. The government might provide annuity products that would spread retirement income over many years and provide insurance against the risk of outliving one's resources. Alternatively, individuals could be required to purchase annuity products from private insurance firms. Another option is to allow individuals to decide whether or not to annuitize any of their assets. The relative attractiveness of these three options depends critically on whether reasonably priced individual annuities are available in the private annuity market.

Most empirical research on annuities markets has focused on the United States. Examples include Friedman and Warshawsky (1988, 1990), Warshawsky (1988), and Mitchell, Poterba, Warshawsky and Brown (hereafter MPWB) (1999). These studies emphasize the limited size of the individual annuity market in the United States, and the non-trivial difference between premium charges and the expected present discounted value of annuity payments for a typical individual. This difference is in part the result of adverse selection. The individuals who choose to purchase annuities in private markets tend to be healthier, and to live longer, than those who do not buy annuities. The extent of such adverse selection is likely to depend on the institutional setting in which annuities are sold.

The annuity market in the United Kingdom is much larger than that in the United States, particularly when scaled relative to population or national output. It has also begun to attract research attention in the context of current Social Security reform discussions. Murthi, Orszag, and Orszag (1999), for example, provide some empirical evidence on the pricing of different products in the U.K. annuity market. At least three features of the British market make it especially valuable for studying the operation of private annuity markets. First, in the United Kingdom there is both a compulsory private annuity market for individuals in various pension schemes, and a voluntary private annuity market for individuals who wish to annuitize some of their non-pension savings. The simultaneous operation of these markets provides an opportunity to 
explore selection effects. Second, the array of individual annuity products in the United Kingdom is richer than that in the United States. Many insurance companies offer fixed nominal annuities, "escalating" annuities with payments that increase in nominal terms, as well as inflation-indexed annuities. This makes it possible to study both how individuals select into the annuity market, as well as how they select into purchase pools for different annuity products. Finally, the general availability of inflation-indexed annuities permits us to investigate the pricing of such annuities relative to nominal annuities. Because index-linked bonds, which were introduced in the United States in 1998, have been available in the United Kingdom for nearly twenty years, the index-linked annuity market in the United Kingdom may provide some indication of how the U.S. annuity market will evolve in the future. Brown, Mitchell, and Poterba (1999) note that there is effectively no market in the United States for index-linked annuity products.

The present paper provides descriptive information on the structure of the annuity market in the United Kingdom, and it presents new empirical evidence on pricing and selection effects in this market. The paper is divided into six sections. The first describes the institutional environment in which both voluntary individual annuities and compulsory annuities are sold. This includes a fairly detailed overview of the two markets and a description of the structure of the principal annuity products.

Section two explores the margins along which adverse selection can operate in annuity markets. It describes both the traditional margin of selection, whether or not to purchase an annuity, as well as adverse selection within the annuity market, as individuals decide which type of annuity to purchase. We present data on the mortality experience of individuals in different annuity markets.

The third section presents a standard framework for evaluating the expected present discounted value of the payments from various annuity products. We describe the data on mortality rates, discount factors, and annuity prices that form the basis of our empirical analysis.

In section four, we report our basic findings on the expected payouts from a number of standard annuity products. The results demonstrate the importance of considering selection effects in evaluating annuity products. We find that voluntary annuitants live substantially longer than randomly selected individuals in the population. The expected present discounted value of a typical voluntary annuity's 
payouts, evaluated using the mortality table for voluntary annuitants, is about thirteen percent higher than the same payout stream evaluated using the mortality risk for the population at large. The payouts associated with a compulsory annuity average between three and eight percent higher than those from a voluntary annuity. This is largely the result of mortality differences between voluntary and compulsory annuitants, which are ultimately reflected in the annuity payouts offered by insurance companies. Our estimates suggest that the cost of adverse selection in the compulsory annuity market is between one third and one half as great as that in the voluntary annuity market.

Section four also presents evidence of selection effects across different types of annuities. The expected present value of inflation-linked annuities is about eight percent lower than that of nominal annuities. The expected present value of 5\% escalating annuities is four to five percent lower than that of nominal annuities. Since both index-linked and escalating annuities offer payout streams with greater real value to those who live longer, relative to those who die early, this pricing pattern is consistent with longerlived individuals choosing to purchase annuities with back-loaded payouts. However, the relative prices of the $5 \%$ escalating and real annuities are not consistent with this pattern.

Section five briefly discusses a selection-related annuity pricing issue: the relative pricing of annuity policies of different size. One of the standard predictions of models of asymmetric information in insurance markets is that insurers should charge higher prices per unit of insurance for larger policies, because those who purchase larger policies are likely to be poorer risks. In fact, we document the opposite pattern in the data on annuities and discuss possible explanations of this finding.

The last section summarizes our major findings, recaps the evidence that we present for the importance of selection effects in the annuity market, and outlines several directions for future work.

\section{The Structure of Annuity Markets in the United Kingdom}

This section describes the institutional structure of the individual annuity market in the United Kingdom. Readers who are already familiar with this market may wish to turn immediately to our analysis of pricing issues in section two. 
There are two different annuity markets in the United Kingdom: a compulsory market, in which individuals face some degree of compulsion in purchasing an annuity, and a voluntary market. The voluntary market is known as the market for "purchased life annuities" and no one is required to participate in it. A variety of annuity products are sold in both markets. Individuals can choose between annuities with payments that are fixed in nominal terms, "escalating" annuities in which the nominal payout increases by a fixed amount each year, and inflation-indexed annuities.

\subsection{Background and Overview of Compulsory and Non-Compulsory Annuity Markets}

A substantial part of the demand for annuities in the United Kingdom is related to the market for private pensions. U.K. pension plans can be either of the defined benefit (DB) variety, in which a retiree is guaranteed a fixed, regular payment based on his salary history, or of the defined contribution (DC) variety. A DC plan, known as a "money purchase pension," entitles the retiree to an amount that is determined by previous plan contributions, which are made from pre-tax pounds and which accumulate pre-tax, and the performance of the associated plan investments. Defined contribution pension plans have compulsory annuitization requirements.

One reason for compulsory annuitization laws for DC pension plans is that these plans may substitute for the State Earnings-Related Pension Schemes (SERPS), which serves as a second-tier system on top of the state flat rate pension. Since its inception in 1978, individuals have been able to "contract out" of SERPS provided that they had a DB pension scheme with a minimum benefit level. The 1986 Social Security Act allowed individuals to contract out of SERPS into DC pension plans as well, as long as these plans collected a specified minimum level of contributions.

Pension plans are available either through an employer, in which case they are called occupational pension schemes and are similar in spirit to 401(k) plans in the United States, or through personal pension schemes, which are similar to Individual Retirement Accounts in the U.S. Occupational pension schemes may be either DB or DC plans, although they are predominantly of the defined benefit type. Budd and Campbell (1998) report that in 1991, only about 900,000 of the 10.7 million employees in occupational pension schemes were in DC schemes. DC plans are currently growing in popularity, however. 
Personal pension plans have been available since 1988 to any individual with earned income. Prior to 1988 , Section 226 retirement annuities, which were similar to the current personal pension plans, were available only to the self-employed and to employees who were not in occupational pension schemes. Both personal pension and section 226 plans are DC plans. By the mid-1990s, Budd and Campbell (1998) report, over 5 million people, most of whom were previously in SERPS, had taken out personal pensions. The Association of British Insurers (1997) reports that there are almost 20 million personal pension or section 226 policies in force.

The compulsory annuity market consists of individuals with Section 226 plans, personal pension schemes, and DC occupational pension schemes. ${ }^{1}$ Currently, personal pension annuitants are likely to be a smaller fraction of the compulsory annuitant business than Section 226 annuitants, since the former are likely to be younger and hence not have retired yet. Budd and Campbell (1998) note that this is due partly to the recent introduction of personal pension plans. In addition, the incentives for contracting out of SERPS are greater for younger individuals.

The compulsory annuity market is large. The Association of British Insurers (1997) reports that in 1996, annual annuity payments to annuitants in the compulsory market totaled $£ 3.9$ billion. Two-thirds of these payments went to individuals who had participated in occupational defined contribution plans, while one-third were to individuals who had section 226 or personal pensions. The voluntary market - which consists of individuals who choose to purchase an annuity from non-pension savings - is considerably smaller. Annual payments to voluntary annuitants in 1996 were only $£ 0.8$ billion. The total amount paid to purchase new immediate annuities in 1996 was $£ 4.2$ billion, with voluntary annuities accounting for just under $20 \%$ of this total. MPWB (1999) report that purchases of immediate individual and joint-and-survivor annuities in the United States accounted for less than $\$ 3$ billion in premiums in the mid-1990s.

\footnotetext{
${ }^{1}$ Although Section 226 contracts are no longer issued, individuals who participated in such plans prior to 1988 are still retiring and therefore buying compulsory annuities.
} 


\subsection{The Detailed Structure of Compulsory Annuitization}

Although individuals with defined contribution pension plans are required to annuitize at least some portion of their accumulated fund, they are given some flexibility in the amount that they annuitize and in timing their annuitization. ${ }^{2}$ A tax-free lump sum may be taken in lieu of annuitizing some portion of the fund, but the amount of this lump sum is limited, since compulsory annuities are purchased using pension funds that were deposited pre-tax. For personal pension schemes the limit is $25 \%$ of the value of the fund at retirement, up to a maximum of $£ 150,000$, and in occupational DC schemes the limit is 1.5 times final salary. ${ }^{3}$ Compulsory annuity payments are treated as taxable income. Individuals cannot take a pension before age 50 ( 45 for women) nor delay taking a pension beyond age 75 (70 for women).

Since 1995, pensions have featured an "income withdrawal option." This allows the individual to delay the purchase of an annuity until age 75 , provided that he or she draws an income from the pension fund that is between 35 and $100 \%$ of the amount that would otherwise be obtained from a nominal annuity. This can be attractive if the pension fund is invested in assets that yield a higher return than that provided by a nominal annuity. In addition, if the pensioner dies before annuitizing, Khorasaneee (1996) explains, assets in the pension fund become part of the pensioner's estate. Thus for a pensioner with a bequest motive, the income withdrawal option may be particularly attractive.

There are few restrictions on the type of annuity that a compulsory annuitant may buy. The "open market option" allows compulsory annuitants to purchase their annuity from life insurance companies other than the one in which their fund has been accumulating. They may also choose the type of annuity and the frequency of payments. For example, the annuitant can buy a single life annuity, for which payment ceases with the death of the annuitant. This is the type of annuity product that we focus on in this paper. The annuitant could alternatively purchase a joint-life annuity that pays a benefit, possibly a reduced benefit,

\footnotetext{
${ }^{2}$ The rules differ somewhat for the portion of accumulated balance that is due to contracting out of SERPS. But, as noted earlier, those contracting out of SERPS tend to be young and they are therefore unlikely to be purchasing annuities. Throughout this paper, the rules we describe apply to the current generation of annuity buyers who are assumed to not have pension balances that are subject to the SERPS rules.

${ }^{3}$ For Section 226 contracts, the maximum lump sum increases with the age of retirement, up to about 30 percent of the accumulated fund. Blake (1995) describes these provisions in detail.
} 
after the death of the first annuitant and until the death of the second. Annuitants may also select a guarantee period of up to ten years. This ensures that the annuity will pay benefits to the estate of the annuitant until the guarantee period is up.

Finally, compulsory annuitants face virtually no restrictions on how the payments from their annuity are determined. They may choose to buy "linked" annuities, which are known as variable annuities in the United States. The payout on these annuities is linked to the performance of the underlying assets. The annuitant can also choose to purchase an annuity with payouts that are specified at the time of purchase. In this case, which is the one we study in this paper, the individual still has many choices regarding the payout profile of the annuity; these are described more fully in the next section. A voluntary annuitant has access to the same set of options.

\subsection{Product Choice in the Annuity Market}

A range of annuity products, offering different payout profiles, are widely available in both the voluntary and compulsory markets. Individuals may purchase a nominal annuity which pays a constant nominal payout each period or an escalating annuity whose nominal payout rises annually by a fixed percentage. Escalation rates of 1,3, and 5\% are commonly available. Annuitants may also purchase an "inflation-indexed" or real annuity whose nominal payout is adjusted each year by the percentage change in the Retail Price Index (RPI). There are no floors or ceilings on the adjustments to the annuity payment that can occur with RPI-linked products. Hence, in a period of deflation, the nominal payment on an inflationindexed annuity would decrease. In addition to insurance against outliving one's resources, an inflationindexed annuity also provides insurance against fluctuations in the aggregate price level.

We have tried, unsuccessfully, to obtain information on the aggregate size of the market for different annuity products. Conversations with several annuity providers suggest that the size of the real annuity market is small. Nevertheless, we do know that real annuities are widely available. We have identified at least eleven insurance companies that offer inflation-indexed products in the compulsory market, and three that offer such products in the voluntary market. The availability of indexed bonds in the United Kingdom since the early 1980s may explain the greater presence of index-linked annuities in the 
U.K. than in the U.S. market, since these bonds permit insurance companies to hedge the inflation risk associated with offering inflation-indexed annuity products.

\section{Adverse Selection in Annuity Markets}

An annuity insures against outliving one's resources. Therefore, from the perspective of an insurance company, a high-risk annuitant is one who is likely to live longer than average. Like other insurance markets, the annuity market may be affected by asymmetric information between the insurer and the insured. Individuals may use private information to decide whether or not to select into the annuity market, and conditional on being in the market, to select which type of annuity policy to purchase. There are no regulations in the United Kingdom on the annuity rates in either the compulsory or the voluntary annuity market, or on the way such rates may vary by age or gender.

\section{$\underline{2.1 \text { Selection Into the Annuity Market }}$}

The traditional analysis of adverse selection in the annuity market recognizes that the average annuitant is longer lived than the average person in the population. The presence of this adverse selection in the voluntary annuity market in the United States has been widely documented, for example by Friedman and Warshawsky $(1988,1990)$ and MPWB (1999). Roughly half of the disparity between the expected present value of annuity payouts and the premium cost of annuity policies in the United States appears to be due to adverse selection.

There should be less adverse selection in a compulsory annuity market. Nonetheless, the rules on compulsory annuitization outlined above suggest several dimensions over which selection can occur even in the U.K. compulsory annuity market. First, individuals who expect to be short-lived may opt to take more of their pension as a lump sum (up to the maximum). Second, such individuals may also find the income withdrawal and delay of annuitization option more appealing. Finally, the set of individuals who are in DC

pension plans may not be a random subset of the population, and their mortality prospects might differ from the average in the population. Although in principle such differences could lead to either higher or lower 
mortality, in practice we suspect that the population in defined contribution pensions is economically more successful, and therefore likely to experience lower mortality, than the population at large.

The mortality rates of annuitants and of other population sub-groups illustrate the potential importance of these selection effects. Mortality tables are available in the U.K. for the population as a whole, for voluntary annuitants, and for a group that is likely to be similar to the compulsory annuitant population. Figure 1 shows the cumulative survival probability for a 65 -year-old male in each of these

Figure 1: Cumulative Survival Probability for 65 year old male (1998 cohort tables)

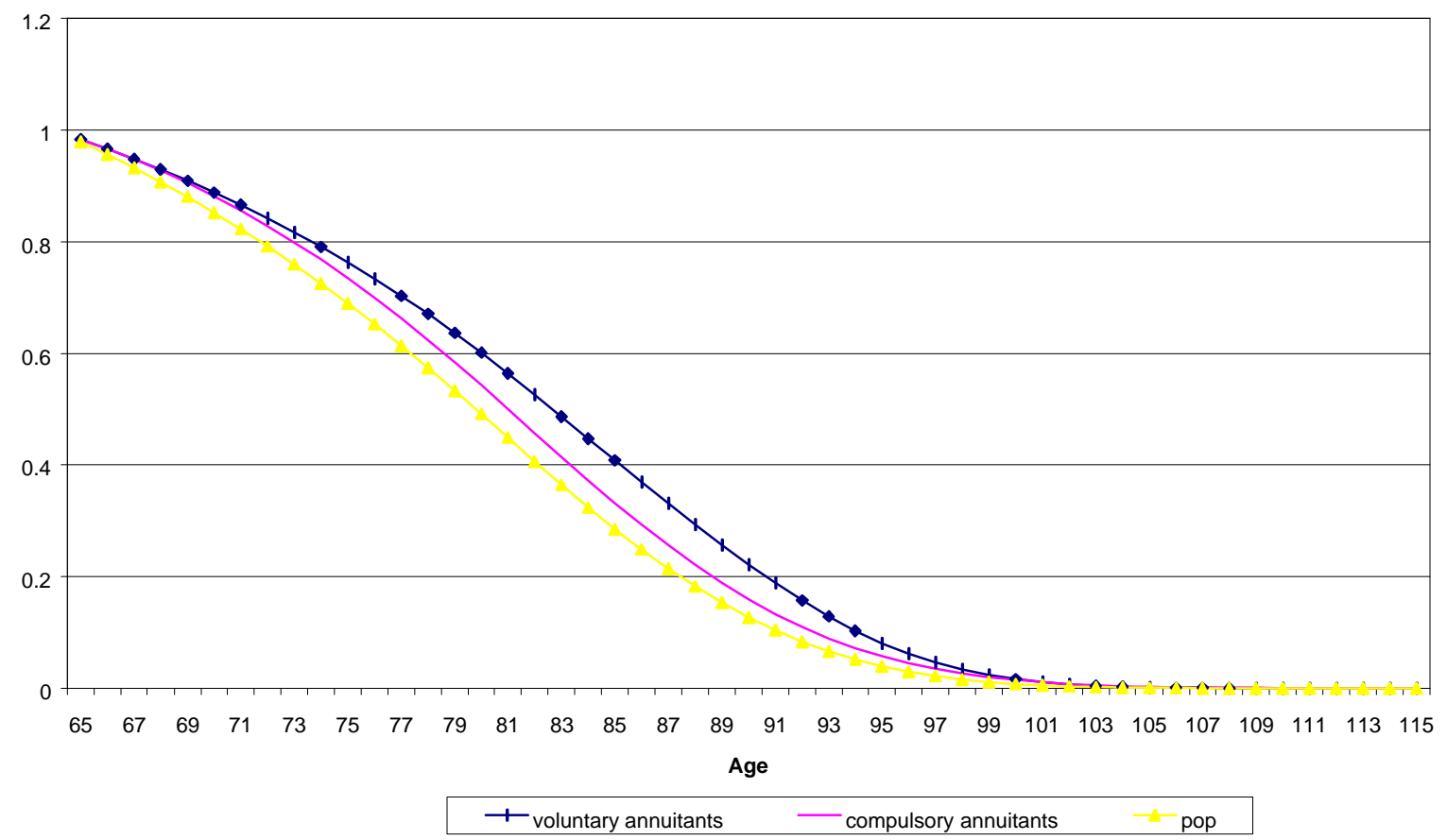

groups. ${ }^{4}$ A higher survival probability curve corresponds to a longer life expectancy. The data show that the average 65-year-old male voluntary annuitant is longer lived than the average 65-year-old male compulsory annuitant, who in turn is longer lived than the average 65 year old male in the population. The pattern holds for women and for older ages as well.

\footnotetext{
${ }^{4}$ The data underlying Figure 1 are reported in Appendix Table A1. Section 3.2 provides more information on the construction of these survival curves. All of the mortality tables used in this paper, unless otherwise noted, are cohort tables, and they are weighted by lives, not by the value of policies purchased. These tables indicate the past or projected mortality of someone who was born into a given age cohort. Projections take into account future mortality improvements. A "period" mortality table, in contrast, is based on the age-specific mortality rates that individuals of different ages face at a given point in time.
} 
These mortality differences shown in Figure 1 could be due to "active selection," in which individuals use private information about their mortality prospects to decide whether or not to purchase an annuity. They could also be the result of "passive selection." Individuals who choose to purchase annuities may have other attributes, such as above-average wealth, that make them less likely to die than individuals in the general population. Attanasio and Hoynes (1995) summarize previous work on, and present new evidence on, the negative relationship between wealth and mortality. The potential for active selection in the annuity market depends in part on whether individuals can rationally forecast their individual mortality prospects. While some very sick individuals may know that they are not likely to live very long, it is not clear whether individuals have information that suggests that they may have an especially long potential lifespan. Hamermesh (1985) and Hurd and McGarry (1997) report evidence on individual forecasts of their own life expectancy and how these forecasts vary with individual attributes.

Figure 2 presents some evidence on selection effects related to the value of annuity purchases. The figure shows the cumulative survival probability of a 65 -year-old male using the mortality curve derived

Figure 2: Cumulative Survival Probability weighted by lives and amounts (1998 cohort table for 65 year old male compulsory annuitant)

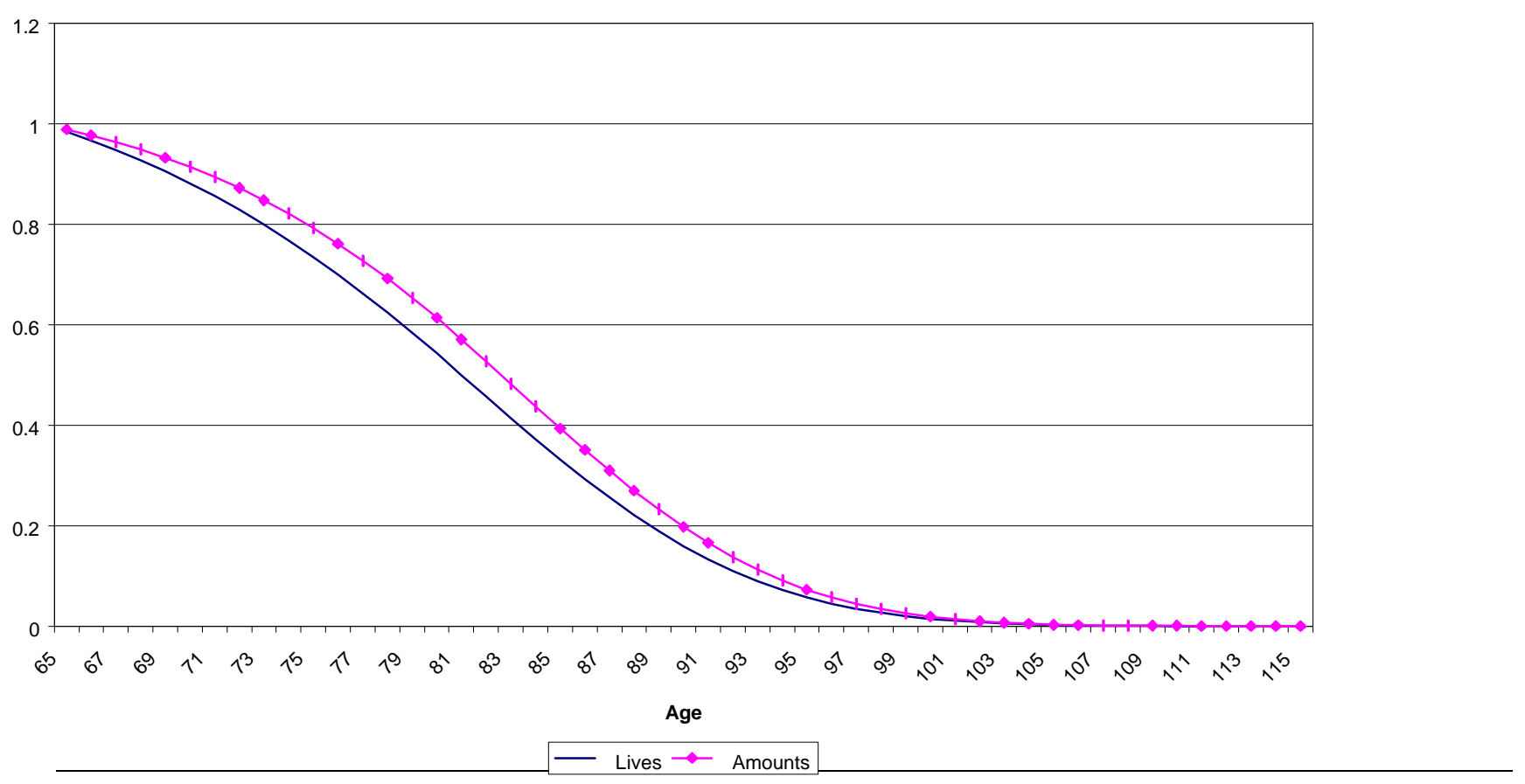


from the mortality experience of compulsory annuitants with each annuitant weighted equally ("lives”). It also shows the mortality experience derived by weighting each annuity buyer by the amount of their annuity purchase ("amounts"). Those who buy larger annuities tend to live longer than those who buy smaller annuities. Once again, the role of active versus passive selection in this pattern is not clear. In an interesting related study, Cawley and Philipson (1999) find that the mortality rate amongst life insurance purchasers in the United States is lower than that amongst those who do not buy life insurance. While this finding is inconsistent with the notion that those with higher mortality risk select into the life insurance market, the passive selection effects we have discussed could explain it.

\subsection{Selection Within the Annuity Market}

In addition to selection effects on whether or not to purchase an annuity, there can be selection effects on the type of annuity purchased. With certain, positive, inflation, a fixed nominal annuity provides a payout stream that is declining in real terms. An RPI-linked annuity, by contrast, provides a payout stream that is constant in real terms. (It also provides some inflation insurance.) The time profile of an escalating annuity depends on the escalation rate relative to the expected inflation rate. The escalating policy we examine rises at a 5\% rate, and long-term expected inflation in the U.K. is well below 5\%; therefore these escalating annuities currently offer a rising real payout stream.

Figure 3 shows the time-profiles of real payouts from three actuarially fair annuities for a 65 year old male given current expected inflation and riskless real interest rates in the United Kingdom. The nominal annuity will initially provide, in real terms, a higher payout than the real or the $5 \%$ escalating annuity. Eventually, as the nominal annuity declines in real terms over time, however, the real payout from the real annuity will exceed that from the nominal annuity. Thus, conditional on buying an annuity, a nominal annuity should be relatively more appealing than a real annuity to individuals with shorter life expectancies.

There are several ways to summarize the differences in the payout profiles of various annuity products. One is the "crossover age," the age at which the real net present value of actuarially fair real annuity payments first exceeds that of nominal annuities. Given current interest rates and inflationary 
Figure 3: Time profile of actuarially fair annuities $(10,000$ premium $)$

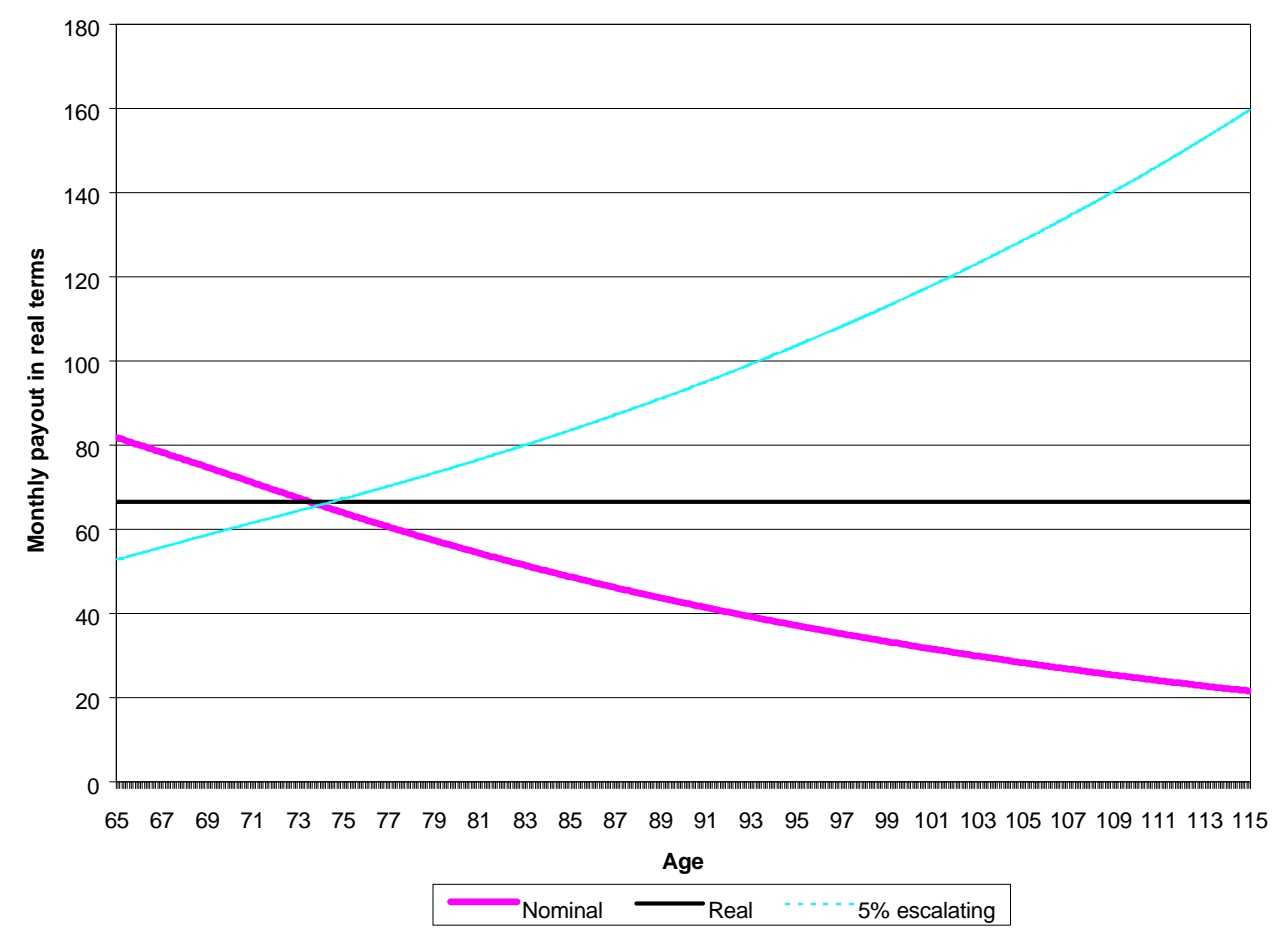

expectations, for a 65-year-old man, this crossover age is 84 . A 65 -year-old man facing population average mortality has a $32 \%$ chance of living until age 84 . A 65 -year-old man facing the average mortality of a voluntary annuitant, however, has a $45 \%$ chance of living to that age.

An alternative and more standard measure of the differential time profiles of different annuity payout streams is the expected duration, or the maturity-weighted average payout date, for the various annuity products. The expected duration (ED) is defined by

$$
E D=\sum_{t=1}^{600}\left[\frac{S_{t} * t}{\prod_{j=1}^{t}\left(1+i_{j}\right)}\right] / \sum_{t=1}^{600}\left[\frac{S_{t}}{\prod_{j=1}^{t}\left(1+i_{j}\right)}\right]
$$

where $\mathrm{i}_{\mathrm{j}}$ is the nominal interest rate when we calculate the duration for a nominal or $5 \%$ escalating annuity, and it is the real interest rate when we perform the calculations for the real annuity policies. The variable $S_{t}$ is the cumulative survival probability for a 65 -year-old male facing the population average mortality curve. The subscript $t$ indexes months; we assume that the survival probability is zero after 600 months (i.e. after age 115 , since we consider annuities that begin at age 65 ). 
Table 1 shows the expected duration of different actuarially fair products for a 65 -year-old male. The payments from a nominal annuity are weighted more toward earlier years than the payments from a real annuity. For any real interest rate and inflation rate, the duration of nominal products is shorter than that of real products. The expected duration of the $5 \%$ escalating annuity is always greater than that of the nominal annuity but the relative durations of the 5\% escalating and real annuities depends on whether the inflation rate is greater or less than 5\%. For inflation rates below $5 \%$, the duration of the $5 \%$ escalating annuity is longer than that of the real annuity.

The expected duration of all types of annuities declines with the real interest rate but the rate of decline varies across product types. The last column of Table 1 shows that the expected duration of the real annuity declines faster than that of the nominal annuity as the real interest rate rises. As a result, higher real interest rates reduce the difference between the expected duration of the nominal and real annuity; they should therefore reduce the amount of adverse selection among annuity product types. Similarly, higher inflation reduces the expected duration of both a nominal and a 5\% escalating annuity, while it leaves the expected duration of a real annuity unchanged. Therefore higher inflation should increase selection between real and nominal products.

Our discussion so far has focused on selection amongst individual annuity products with different real payout profiles. It is also possible that there are selection effects across different types of annuity policies, for example policies with and without guaranteed payout periods, and across individual rather than joint-and-survivor annuity policies. These are issues we plan to explore in future research.

\section{Evaluating the Money's Worth of Various Annuity Products}

A standard approach to quantifying the difference between the actuarially fair payout from an annuity product, and the actual payout, is to calculate the expected present discounted value (EPDV) of annuity payments and to compare the result with the annuity premium paid. The ratio of EPDV to the premium is known as the annuity's money's worth. MPWB (1999) describe this framework in detail.

\subsection{The Basic Framework}


The EPDV of monthly, single life, annuity payments for various products are given below:

$$
\begin{aligned}
& E P D V_{N O M}=\sum_{t=1}^{T} \frac{A_{N O M} * S_{t}}{\prod_{j=1}^{t}\left(1+i_{j}\right)} \\
& E P D V_{R E A L}=\sum_{t=1}^{T} \frac{A_{R E A L} * S_{t}}{\prod_{j=1}^{t}\left(1+r_{j}\right)} \\
& E P D V_{5 \% E S C}=\sum_{t=1}^{T} \frac{A_{5 \% E S C} *(1.05)^{t / 12} * S_{t}}{\prod_{j=1}^{t}\left(1+i_{j}\right)}
\end{aligned}
$$

In these expressions A denotes the monthly payout of the specified product, and $S_{t}$ denotes the probability that the annuitant survives until period t. The payouts $A_{N O M}$ and $A_{5 \% E S C}$ are nominal payouts, while $A_{R E A L}$ is a real payout. We use two sets of interest rates: $i_{j}$ denotes the expected one-month nominal interest rate at time period $\mathrm{j}$ and $r_{j}$ denotes the expected one-month real interest rate at time period $\mathrm{j}$. In practice, annuity payments for escalating and real products are not adjusted monthly, but annually. We account for this actual adjustment process in our calculations below.

The EPDV/Premium ratio, the money's worth of the annuity, would be unity if the annuity were actuarially fair. Values below one can be attributed to a variety of factors, of which adverse selection is only one. (Others include administrative costs and taxes on the insurance companies offering annuities.) If the EPDV is calculated using the population mortality table, but annuitants are longer lived than average and insurance companies set annuity payouts accordingly, then the EPDV will fall below the premium cost of the annuity. Calculations of EPDV using annuitant mortality tables should result in money's worth values closer to unity. Even using an annuity mortality table, the money's worth may not be unity. We do not have mortality tables based on the experience of individuals purchasing particular annuity products, but rather, tables based on the "annuitant population." Selection effects within the annuity market could result in some money's worth values falling below unity.

We can estimate the effect of adverse selection on annuity pricing in two ways. First, we can compare money's worth estimates in different annuity markets, where we believe the potential for adverse 
selection differs. If the other components of loading factors are constant across the markets for different annuity products, the difference in money's worth values should reflect differences in adverse selection. If product A has a lower money's worth than product B, we will conclude that product A is purchased by individuals who are "more adversely selected" than those who purchase product B.

As a second research strategy, we can use mortality tables for different annuity markets. We have separate annuitant mortality tables for the compulsory and voluntary annuity markets. We can therefore compare the EPDV of payouts in the voluntary market calculated using the voluntary mortality curve to the EPDV calculated using the population mortality curve. We attribute the disparity in these two calculations to adverse selection. We can do the same comparison in the compulsory market, comparing the EPDV of compulsory payouts evaluated using the compulsory mortality table to those evaluated using the population mortality table. We can thus compare selection differences across the two markets. Unfortunately, we cannot apply this second strategy to compare the selection between different annuity products, because we do not have product-specific mortality tables.

\subsection{Mortality and Interest Rates}

Equations (2a)-(2c) indicate that calculating the EPDV of an annuity requires information on the term structure of real and nominal interest rates, a mortality table, and the annuity payments for different products. This section describes the data we use for interest rates and mortality risk.

For the term structure, we use the zero coupon yield curve of nominal and index-linked Treasury securities. We have data on semiannual yields for maturities up to 25 years. We convert these to monthly spot rates, and assume the spot rate for 25 years forward applies at all dates beyond the 25-year horizon. We use a term structure coincident with the date at which our data on annuity prices was collected. ${ }^{5}$ We follow a number of earlier studies on annuity values in using riskless interest rates to discount annuity payouts. If we used a term structure corresponding to risky interest rates, the money's worth of the various annuity products would be lower than our calculations suggest. 
We use three different mortality tables in our calculations below. First, we use the projected survival probabilities for the United Kingdom population. The Government Actuary's Department of H.M. Treasury compiles these mortality tables. ${ }^{6}$ We use the most recent available population projections, which are from 1996.

We also use two mortality tables that reflect the mortality experience of voluntary and compulsory annuitants. These are based on information compiled by the Institute of Actuaries with regard to the mortality experience of male and female voluntary annuitants and of male and female "life office pensioners." We use the mortality experience of "life office pensioners" as a proxy for that of compulsory annuitants. Life office pensioners are individuals in insured occupational pension schemes.

Whether life office pensioners are representative of compulsory annuitants is not clear. On the negative side, the compulsory market also includes individuals in personal pensions and section 226 plans. Furthermore, life office pensioners may not even be representative of individuals in defined contribution occupational pension schemes. The vast majority of life office pensioners are in defined benefit pension schemes, rather than in the defined contribution schemes that form part of the compulsory annuity market. And life office pensioners are likely to be disproportionately from small firms, as larger firms are more likely to self-insure. However, the case for comparability between life office pensioners and compulsory annuitants is strengthened by the fact that the same sort of active selection effects, such as deferring annuitizing and taking a lump sum, are available in both markets. Moreover, individuals are allowed to transfer money from occupational pensions to personal pensions when they change jobs. This may further homogenize the two groups. The net effect of these various factors is unclear, so in the absence of better information, we apply the life office pensioner mortality table to the compulsory annuity market.

Both the voluntary annuitant tables and the life office pensioners tables, hereafter referred to as the compulsory annuitant table, are period tables based on the past mortality experience of their respective

\footnotetext{
${ }^{5}$ We have two sets of data on annuity prices. One set (which is the basis for calculations in section 4 ) is from November 6, 1998 and for this we use a November 5, 1998 term structure. The other set (which is the basis for the calculations in section 5) is from August 21, 1998 and for this we use an August 26, 1998 term structure.

${ }^{6}$ These mortality tables assume that no one survives beyond age 112 .
} 
populations. The most recent voluntary annuitant tables, which are published in the Society of Actuaries' Continuous Mortality Investigation Report \#10 as the "IM80" and "IF80" series, are based on the mortality experience of voluntary annuitants in 1979-1982. We treat these tables as reflecting the mortality experience of voluntary annuitants in 1980. The most recent compulsory annuitant tables, which are published in the Continuous Mortality Investigation Report \#16, are based on the mortality experience of life office pensioners in 1991-1994. We treat these tables as reflecting the mortality experience of compulsory annuitants in 1992.

There are two problems with using older tables, particularly ones as old as the voluntary annuitant tables, to value annuity payouts. First, changes in pension and annuitization law since 1980 may have led to changes in the population of voluntary annuitants, and hence in the degree of adverse selection relative to the population at large. For example, in 1980 personal pensions did not exist, and contracting out of SERPS into defined contribution pension plans was not permitted.

Second, older tables need to be updated to take account of mortality improvements. To update the older period tables to 1998 period tables, we assume that the mortality improvements in these annuitant populations have been the same as those experienced by the general U.K. population. We compute the ratios of conditional death probabilities $\left(\mathrm{q}_{\mathrm{x}}\right)$ in the 1998 U.K. population period table, based on 1996 projections, to those in the 1980-1982 U.K. population period table. We compute age- and gender-specific ratios and annualize them to estimate the annual mortality improvement for each age and gender cell. We then use these annual mortality improvements to "age" the 1980 male and female voluntary annuitant period mortality tables to 1998 voluntary annuitant period mortality tables. We update the 1992 compulsory annuitant period mortality table using a 1990-92 U.K. population period table to compute the q ratios.

One remaining difficulty is that the annuitant mortality tables are period mortality tables, not cohort tables. Period tables describe the mortality rates of individuals at different ages in a given year. Cohort tables describe the mortality experience for a given birth cohort as it reaches different ages. To value an annuity purchased by a 65-year-old today, we need a cohort table rather than a period table. The chance that the annuitant will die at age 70, having survived until that age, depends on the mortality rate of 70-year-olds 
five years from now, not on the mortality rate of a current 70 -year-old. The former would be found in a cohort mortality table for someone aged 65 today, while a current period table would show the latter.

To turn 1998 period tables into cohort tables, we assume that projected mortality improvements for the U.K. population are the same as for these annuitant groups. We therefore compute the ratio of age- and gender-specific mortality in the 1998 U.K. population cohort mortality table and the 1998 U.K. population period mortality table, and we use these ratios to "cohortize" our 1998 annuitant period tables. The resulting cohort mortality tables are reported in Appendix Table A-1.

\section{$\underline{3.3 \text { Annuity Prices }}$}

The final input that we need for the calculations in equations (2a) through (2c) is data on the payments offered by different annuity products. We contacted several annuity brokers in the United Kingdom. They supply information on the rates offered on various annuity products by various life insurance companies. The brokers provide rates that are specified by age, gender, type of product (nominal, real or escalating), market type (compulsory or voluntary), purchase price, frequency of payments, guarantee period, and degree of survivor benefits. Conversations with several annuity providers indicated that there are no other characteristics of an annuitant that would be used in setting the annuity rate, although some companies offer special rates to individuals likely to be in poor health, such as smokers. The set of firms identified by these different brokers is similar, so we suspect that we have identified most of the major annuity providers. Khorasanee (1996) provides support for this view, reporting that as a result of the open market option, most U.K. annuity business is written by a relatively small number of firms.

To make comparisons across markets and across products, as we do in the next section, we use a data set provided by the annuity broker "Moneyfacts." The data set contains information on nominal, real, and 5\% escalating products in both the compulsory and voluntary markets. Moneyfacts, however, only provides information on annuities that can be purchased for $£ 10,000$. To compare how money's worth varies with the premium, we also use another data set on annuity prices supplied by "Annuity Direct." This data set includes rates for compulsory annuities with $£ 10,000, £ 50,000$ and $£ 100,000$ premia. Throughout our analysis, we restrict our attention to single life annuities. 
Table 2 presents summary statistics on the average initial monthly payments for different annuity products that are available in the compulsory and the voluntary annuity markets. ${ }^{7}$ Initial payments are higher for annuities with nominal payouts than for those with real payouts, and higher for real products than for $5 \%$ escalating products. The table also indicates that average payments are higher in the compulsory than in the voluntary market, which is consistent with greater adverse selection in the voluntary market. Average payments are also higher for men than for women, reflecting the greater life expectancy for women and the correspondingly longer time over which the insurer expects to make annuity payments.

The average payments listed in Table 2 mask substantial variation across firms in the rates offered for a given product-market-gender-age cell. Table 3 summarizes this variation by reporting coefficients of variation for each of the annuity product/market combinations. There is greater variation in the pricing of real and escalating annuities than in the pricing of nominal annuities. This is evident in both the compulsory and the voluntary market. This variation for ostensibly very similar financial products suggests that individuals with the same amount to annuitize at their date of retirement could potentially receive very different lifetime income streams as a result of variation in the terms of individual annuity products.

Different insurance companies offer different annuity products. Since the set of providers offering a given annuity product differs across products, differences in money's worth values across markets or across products within a market could be driven simply by differences in the set of insurers offering different products. ${ }^{8}$ Table 4 shows the number of insurance companies offering each type of annuity product. The number of firms offering compulsory annuities is larger than the number offering voluntary annuities, and the number offering inflation-indexed annuities is smaller than those offering nominal or 5\% escalating annuities. In some of our subsequent calculations, to ensure comparability of our calculations in different markets, we limit our attention to the prices of products offered by insurers who are active in all relevant annuity markets.

\footnotetext{
${ }^{7}$ All calculations in this section are based on the Moneyfacts data. The Annuity Direct data, where comparable, show similar patterns.
} 


\section{Evidence of Adverse Selection}

In this section we present our basic money's worth findings and document patterns in the money's worth of private annuities by age and by gender. We then examine the importance of selection effects in the compulsory and non-compulsory market, and between different product types within each market.

\section{$\underline{\text { 4.1 Basic Money's Worth Results }}$}

Table 5 presents money's worth calculations using our entire sample of price data along with population mortality tables. Because the sample of firms offering products is not the same for all products and markets, comparisons of money's worth results across columns must be viewed with caution. But the comparison across the rows reveals a consistent pattern. Money's worth values decline with age, a pattern that MPWB (1999) also report in the U.S. data. There is no clear pattern of relative money's worth values for men and for women. For a 65 -year-old male annuity buyer in the United Kingdom, purchasing a voluntary, nominal annuity, the expected present discounted value of annuity payouts is 0.861 times the amount of the policy premium. This assumes that the annuity buyer faces the mortality prospects of a typical individual in the U.K. Poterba and Warshawsky (1999) present comparable findings for the United States, and conclude that the analogous money's worth value there is 0.850 . For a 65 -year old woman in the United Kingdom, the money's worth value is 0.851 . These findings suggest that a potential annuitant gives up approximately 15 percent of the amount of the annuity purchase in order to obtain insurance against outliving his (or her) resources.

\section{$\underline{4.2 \text { Comparison of Selection Effects in Compulsory and Voluntary Markets }}$}

The results in Table 5 also suggest that the money's worth of annuity products in the compulsory annuity market is substantially greater than that of products in the voluntary market, when both are evaluated using population mortality tables. However, the money's worth calculations in Table 5 are based on the average monthly payout values for all $£ 10,000$ annuity policies that are included in our database. This implies that the set of firms offering the products in one column of the table may differ from the set offering the products in another column. To provide clearer evidence on the relative pricing of annuities in

\footnotetext{
${ }^{8}$ The set of firms in a given product-market cell is the same across different ages and both genders.
} 
the compulsory and voluntary markets, we construct comparable money's worth calculations by limiting our sample to the nine insurance companies that offer both nominal and escalating products in both markets. We do not include real products because this would involve limiting the sample to only three firms.

Table 6 presents money's worth calculations using population mortality tables and the average payments from this subsample of insurers. This table indicates that the money's worth of annuities offered in the compulsory market is substantially higher than that for annuities offered in the voluntary market. For nominal products, the voluntary market's money's worth is between three and five percent lower than the compulsory market's money's worth, depending on the age and gender of the annuitant. For escalating products, the difference ranges from four to eight percent.

One way to quantify the difference in selection effects into the two markets is to consider what proportional reduction in conditional death probabilities $(\mathrm{q})$ at all ages would be required to raise the money's worth in the voluntary market to that in the compulsory market. For a 65-year-old man in the nominal annuity market, all of the death rates in the population mortality table would need to decline by 11 percent to equate the money's worth of a voluntary nominal annuity, evaluated using this modified mortalty table, to that of a compulsory nominal annuity, evaluated using the actual population mortality table. This provides one measure of the degree of selection on mortality experience that would be needed to rationalize the difference in annuity payouts between the voluntary and compulsory annuity markets. For a 65-year-old woman, an even greater reduction in mortality rates, twenty percent, is required to achieve comparability between voluntary and compulsory nominal annuities. In the market for 5 percent escalating annuities, it is also the case that the required mortality rate reduction is larger for 65 -year-old women (17 percent) than for men (12 percent).

The money's worth calculations in Tables 5 and 6 apply a common mortality table, that for the population at large, to the set of payouts available on annuity products offered in different markets. They ask the counterfactual question, "How attractive would the annuity products available in various markets be from the standpoint of a given individual?" While we have assumed that this individual faces the population mortality table, similar relative rankings of the money's worth values from different policies would emerge 
if we used other mortality tables, such as an annuitant mortality table, as well. The crucial message of selection effects, however, is that the individuals who purchase annuities in different markets are not the same. From the standpoint of an insurance company offering both voluntary and compulsory annuities, for example, judging whether one type of annuity offers a higher profit margin than another requires information on the mortality experience of the type of individuals who actually purchase annuities in the different markets. The money's worth values for different types of annuities may differ when they are evaluated using a common mortality table, even though they may be the same when the money's worth in each market is evaluated using the mortality table that applies on average to that market's buyers.

To explore this possibility, Table 7 presents money's worth values that are computed using the same sample of annuity products as that in Table 6 , but now using the mortality tables that apply to annuity purchasers in each market. For completeness, we report the money's worth for products in each market using each of the three different mortality tables that we have constructed, but we show in bold the money's worth values that use the mortality table that applies to each market. The results suggest much less variation in the money's worth values across markets than the calculations in Table 6 implied. The money's worth of compulsory products evaluated using the compulsory mortality table and that of voluntary products evaluated using the voluntary mortality table are roughly similar. This means that the money's worth that the average voluntary annuitant gets on a voluntary product is roughly the same as the money's worth that the average compulsory annuitant gets on a compulsory product. Differences in the money's worth values between the compulsory and voluntary markets are therefore largely the result of differences in mortality in the two groups of annuitants.

Specific results underscore these findings. In the compulsory market, a 65 year old male annuitant who faces the compulsory-annuitant-average mortality receives a 5.2\% higher money's worth on a nominal product $(0.944 / 0.897=1.052)$ and a $7.4 \%$ higher money's worth on an escalating product than a 65 year old male with population-average mortality. Similar differences emerge for men at age 70 . For women at both ages, the differences between the money's worth values calculated using the compulsory annuitant mortality table, and that using the population table, are smaller than those for men. 
The difference between the money's worth results using population and annuitant mortality are even more dramatic in the voluntary annuity market. A 65 year old male annuitant who faces the voluntaryannuitant-average mortality experience receives a $10.1 \%$ higher money's worth on a nominal product and a $15.6 \%$ higher money's worth on an escalating product than a 65 year old male with population-average mortality experience.

Evaluated in absolute terms, the cost of adverse selection in the compulsory market, for 65-year-old men buying nominal annuities, is 4.7 percentage points $(.944-.897)$. In the voluntary market, the results in the right panel of Table 7 show that the cost of adverse selection is 8.8 percentage points $(.953-.865)$. This is the difference between the money's worth value computed using the voluntary annuitant mortality table (0.953) and that computed using the population mortality table (0.865). Hence, for a 65-year-old man purchasing an annuity, the cost of adverse selection in the compulsory market is about half (4.7/8.8) of that in the voluntary market.

For men and women at ages 65 and 70, Table 8 reports the cost of adverse selection associated with the compulsory annuity market relative to the cost of adverse selection in the voluntary annuity market. The results show that in some markets, as much as two thirds of the adverse selection cost in the voluntary market, relative to the population mortality table, is eliminated in the compulsory annuity market.

The difference between the money's worth value using the population mortality table, and that using the compulsory or voluntary annuitant mortality table as appropriate, is a measure of the degree of adverse selection in each annuity market. It is possible to calculate the share of the "cost of insurance" for a given annuity product, calculated using the population mortality table, that is attributable to differences between the mortality experiences of those who purchase this annuity and those in the population at large. This "cost

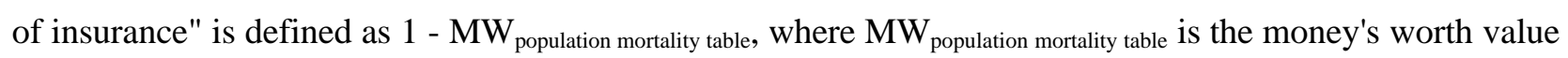
reported in the first or fourth column of Table 7. The share of this "cost of insurance" that is due to adverse selection is the difference between the money's worth value calculated with the relevant annuitant mortality table, and that calculated using the population mortality table: (MW annuitant mortality table $-\mathrm{MW}_{\text {population mortality }}$

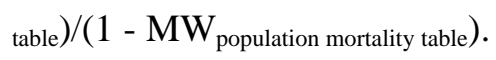


Table 9 reports the results of these calculations. It shows that for men, roughly two thirds of the deviation between the money's worth of voluntary annuities, evaluated using the population mortality table, and 1.0, the value for an actuarially fair annuity, can be attributed to differences between the mortality experience of voluntary annuitants and the population at large. The share is smaller, about one third, for annuities offered to women in the voluntary annuity market. In the compulsory market, depending on whether we focus on age 65 or age 70 , the share of the "insurance cost" that is due to adverse selection is roughly between 35 and 45 percent for men, and between 15 and 20 percent for women.

\subsection{Selection Among Product Types Within Annuity Markets}

The calculations in Tables 7 through 9 suggest that there is more adverse selection in the voluntary market for nominal annuities than in the compulsory market for nominal annuities. They support a similar conclusion with respect to escalating annuities. The tables do not, however, provide direct evidence on the degree of adverse selection across product types within a given annuity market.

To address this question, we focus on the set of eleven insurance companies that offer all three types of annuity products in the compulsory annuity market. We then evaluate the money's worth of the average annuity policies offered by these firms, for men and women of different ages, using a common mortality table. We chose the population mortality table, because this table does not involve any extrapolation or imputation, but the calculations could be performed, and would yield similar results, using other mortality tables as well. Table 10 shows our resulting money's worth calculations. Consistent with the view that real annuities are relatively more appealing than nominal annuities to longer lived individuals, we find that the money's worth of real annuities is between 7 and 9 percent lower than that of nominal annuities. For a 65 year old man, the money's worth of an inflation-indexed annuity is .822, or about 92 percent of the money's worth for a nominal annuity. As a result, for a 65 year old man, an $18 \%$ reduction in death rates at all ages would be required to equate the money's worth of a real annuity, evaluated using this modified mortality table, and a nominal annuity evaluated using the population mortality table. For a 65 -year-old woman, the corresponding reduction in all death rates is $24 \%$. The findings suggest that an annuitant who faces the 
population mortality table, and who wishes to purchase longevity insurance as well as inflation insurance in the compulsory market, will give up between 18 and 21 percent of his wealth for this insurance.

Across all ages and both genders, there is a consistent pattern of lower money's worth values for escalating annuities than for nominal annuities, and lower still for real annuities. Our theory of selection among annuities with different payout profiles is consistent with the finding that the money's worth of escalating annuities is 4 to 5 percent lower than that of nominal annuities. But if selection among product types is based on the time-profile of annuity payments, with longer-lived potential annuitants choosing policies with more backloaded payouts, we would also expect that selection would be more pronounced for 5\% escalating annuities than for real annuities. However, the results in Table 10 do not support this prediction. The money's worth of 5\% escalating annuities is consistently between that of nominal and real annuities, not below that of real annuities. The money's worth for escalating annuities is roughly four percent higher than that of the corresponding real annuities offered to individuals at various ages.

Table 11 presents further evidence on this relationship between the pricing of real and escalating annuities. It reports money's worth values calculated using price quotes from the three insurance companies that offer nominal, real and escalating annuities in the voluntary annuity market. These firms also offer the same three products in the compulsory market, although with different payouts. The results in Table 11 show that in the voluntary annuity market, as well as in the compulsory annuity market, the payout on 5\% escalating annuities is higher than that on real annuities.

There is another puzzle in Table 11. For women and for 65 year old men, the money's worth values in the voluntary market for inflation-indexed annuities are higher than those in the compulsory market for the same product. This is difficult to reconcile with our earlier discussion of greater adverse selection in the voluntary rather than the compulsory annuity market.

The comparative money's worth results that we presented prior to Table 11 were generally supportive of the notion that longer-lived individuals are more likely to purchase annuities, and that conditional on purchasing annuities, they are more likely to purchase products with back-loaded payout structures. The relative pricing of real versus escalating annuities is not consistent with this view. 
This finding could be explained by a number of factors. One is that there are brief lags in the adjustment of the price of index-linked bonds in the United Kingdom to changes in the price level, so that insurers may bear some inflation risk when they offer inflation-linked products. They may charge for this inflation risk by offering less attractive terms on inflation-indexed annuities. Another possibility is that our claim that $5 \%$ escalating annuities offer a more backloaded stream of payouts than inflation-indexed annuities is not shared by potential annuity buyers. Our claim is based on analysis of the inflationary expectations that are embedded in the term structures for real and nominal interest rates in the United Kingdom. If annuity buyers have different inflationary expectations, and in particular if they believe that there is a substantial chance of inflation rates of more than five percent per year for a prolonged period, then our claim about relative payout structures will no longer hold. Yet a final possibility, which may be the most likely, is that the market for inflation-linked annuities is quite limited, so that insurance companies are not transacting much business at their posted prices. We hope to address these issues in future work.

\section{Policy Size and Adverse Selection}

Our analysis so far has focused on comparisons of different types of annuity policies that have the same initial premium. The data that we have collected on the U.K. annuity market also permit us to make some comparisons across policies that differ in their initial premium.

Theory does not make any clear prediction regarding how premium variation should affect the money's worth of an annuity policy. Two factors suggest that money's worth values should decrease with premium size. First, since wealthier households are more likely to purchase larger annuities, and wealthier households tend to be longer lived than their less wealthy counterparts, money's worth should decrease with premium size. This is a result of the "passive selection" on mortality risk that we described above. Second, models of the insurance market under asymmetric information such as those developed by Rothschild and Stiglitz (1976) and Wilson (1977) suggest that higher risk individuals, who in the annuity market are longerlived individuals, purchase more insurance than lower risk individuals. This "active selection" effect also suggests that price of purchasing marginal increments of insurance (the "marginal money's worth") should 
decrease with premium size. In support of these selection effects, Figure 2 presented evidence that people who buy larger annuities tend to live longer than people who buy smaller annuities.

In the presence of fixed per-policy costs, however, it could still be possible for the average cost of insurance, which corresponds to the money's worth values that we report, to decline as a function of policy size. Some costs, such as the administrative costs associated with setting up an account, are not affected by the size of an annuity policy. If the ratio of such costs to the annuity premium declines as the premium rises, the money's worth of larger annuity policies could exceed that for smaller policies.

Even if these fixed cost considerations did not dominate the size-related selection effects, insurers might not be able to offer less attractive terms on annuities with larger premiums than on annuities with smaller premiums. Annuity buyers could always purchase several smaller annuities rather than one large one. If money’s worth were considerably lower for annuities with a $£ 100,000$ premium than for those with a $£ 50,000$ premium, prospective buyers would presumably purchase two $£ 50,000$ annuities, possibly from different insurers, rather than a single larger policy. ${ }^{9}$

To explore the impact of policy size on annuity pricing, we compare the money's worth calculations for compulsory annuity products with $£ 10,000, £ 50,000$ and $£ 100,000$ premia. Our data are drawn from Annuity Direct, which reports information on fourteen firms that offer nominal compulsory products. All but one of the fourteen firms in the Annuity Direct database for nominal compulsory products, however, is also in the Moneyfacts database. ${ }^{10}$ Table 12 reports our findings for nominal annuities with different premium amounts. The same pattern emerges for real and escalating annuities although we do not report those results. ${ }^{11}$

\footnotetext{
${ }^{9}$ Offering insurance rates that vary with quantity of insurance purchased requires that insurers be able to monitor the total amount of insurance that each buyer purchases. This may be particularly difficult in annuity markets. Unlike many insurance markets where payment occurs when an event (such as death) occurs, with annuities, payment occurs until an event (death) occurs. For most insurance products, the insurance company can stipulate that the contract is valid only if the insured has not purchased other insurance, and investigate compliance upon submission of a claim. Doing this with annuities would require continuous monitoring, as Abel (1986) and Brugiavini (1993) have noted in their discussions of adverse selection in annuity markets.

${ }^{10}$ The ages presented in Table 11 differ from those in the previous tables because Annuity Direct did not provide information on rates for 75 year olds.

${ }^{11}$ These data show the same variation in money's worth by age and gender as the Moneyfacts data analyzed in the previous section. The Annuity Direct products all come with a five-year guarantee, so that the data are not directly
} 
The findings in Table 12 suggest a consistent pattern for all ages and for men and women. The money's worth is higher for annuities with $£ 50,000$ and $£ 100,000$ premia than for those with $£ 10,000$ premia, although it is slightly lower for policies with $£ 100,000$ premia than $£ 50,000$ premia. This suggests that the administrative cost savings from $£ 50,000$ and $£ 100,000$ premia compared to $£ 10,000$ premia swamp both the active and passive adverse selection effects that might be associated with larger premium policies. ${ }^{12}$ The slight decline in money’s worth between the $£ 50,000$ and $£ 100,000$ premia may indicate a decline in administrative cost savings once policies reach a sufficiently large premium level. The difference in money's worth between these two products is small, however, which is consistent with the constraints that individual purchasing discretion imposes on quantity-related prices in the annuity market.

\section{Conclusions}

Our findings provide new evidence on the functioning of private annuity markets. The rich structure of the U.K. annuity market, with both a range of different policy types and a substantial pool of annuity buyers, provides a valuable opportunity to explore issues that cannot be studied in many other annuity markets. In particular, studying the U.K. market provides a very valuable complement to previous work on the small nominal annuity market in the United States.

Our analysis suggests several conclusions. First, the cost of adverse selection in the U.K. voluntary annuity market is substantial. From the standpoint of an average male in the population, adverse selection explains $65 \%$ of the difference between the payouts associated with private annuities, and the payouts that would be available if these products were actuarially fair. The comparable figure for the U.S. market is $50 \%$. Second, the money's worth of annuity policies increases with premium size, suggesting that savings from administrative costs on larger policies swamp any increases in selection as premium size rises.

comparable to the Moneyfacts data. We account for the five year guarantee in our analysis by setting the five year survival rate to unity in our EPDV calculations. Thereafter, we use survival rates as in our previous calculations. ${ }^{12}$ These findings are consistent with Cawley and Philipson's (1999) finding of "bulk discounts" in the U.S. life insurance market. 
Third, our results suggest that adverse selection in compulsory annuity markets is substantially less important than adverse selection in completely voluntary annuity markets. Individuals who have accumulated retirement assets in a broad class of retirement saving schemes are required to annuitize at least part of their saving balance. While the individuals who participate in such saving programs are unlikely to be a random cross-section of the U.K. population, they appear to be a more representative sample than the set of individuals who voluntarily purchase private annuities. The money's worth of what we label "compulsory" annuities is three to eight percent higher than the money's worth of voluntary annuities. Alternatively, our estimates suggest that the degree of adverse selection in the compulsory annuity market is roughly half to a third as great as that in the voluntary annuity market.

These results may be helpful in thinking about designing Social Security reforms that involve switching from defined benefit to defined contribution systems. With a defined contribution system, the government must decide whether to require annuitization upon retirement. The U.S. Congressional Budget Office (1999) discusses the importance of annuity markets in more detail, with particular attention to the fees and associated costs of private annuity markets. Our analysis suggests that the cost of adverse selection in a voluntary market is large, and that even a relatively flexible mandatory annuitization system such as the one in the U.K. can substantially reduce this cost.

Finally, our results highlight the scope for selection across different product types, even in a compulsory annuity market. We find that the money's worth for an annuity product with a rising nominal payout stream is about five percent lower than that for a level nominal product. The money's worth for an annuity with an inflation-indexed payout stream is about eight percent lower than that for an annuity with a level nominal payout. Since nominal, real, and escalating annuities offer payouts with different real profiles over time, they will appeal differently to individuals with different life expectancies. When individuals are free to choose among product types, even when participation in the broadly-defined annuity market is compulsory, we find that the resulting degree of adverse selection can be substantial. This implies that there may be a tradeoff between allowing individuals to choose among annuity products, to find one that best matches their risk and time preferences, and avoiding adverse selection in the market for each annuity type. 
One interesting feature of the U.K. annuity market is the opportunity to observe the simultaneous operation of markets for real and nominal annuities. We have not been able to find data on the relative size of the nominal and real annuity markets in the United Kingdom, but a number of anecdotal reports suggest that the real annuity market is much smaller than the nominal market. This may simply be a consumer reaction to the current pricing of real and nominal annuity products.

We find that the money's worth of nominal annuities is greater than that of real annuities, so that potential annuity purchasers must pay more to purchase both longevity insurance and inflation insurance than to purchase longevity insurance alone. This is true even though inflation-indexed government bonds provide insurers with an opportunity to avoid most of the inflation risk associated with inflation-indexed annuity products.

Future work could usefully try to analyze the extent to which individuals value inflation protection, and to study the factors that influence the relative prices of real and nominal annuity products. It would also be useful to trace the evolution of the real annuity market since the introduction of inflation-indexed bonds in the early 1980s, and the impact of real and nominal interest rate movements on the money's worth of escalating, nominal, and real annuities.

Another direction for future research involves studying the determinants of adverse selection in different annuity markets. It may be possible to use changes over time in the number of individuals covered by compulsory annuitization requirements to study the degree of adverse selection in voluntary and compulsory annuity markets. The secular growth of occupational defined contribution plans, the introduction of personal pension plans in 1988, and the 1986 expansion of opportunities for "contracting out" of SERPS and into defined contribution plans, have all affected the size of the compulsory annuity market. Studying how the voluntary and compulsory annuity markets have responded to such changes could provide useful evidence on how Social Security reforms in the United States and other nations, which could substantially increase the demand for individual annuities, might affect annuity pricing. 


\section{BIBLIOGRAPHY}

Abel, Andrew B. 1986. Capital Accumulation and Uncertain Lifetimes with Adverse Selection. Econometrica, (September), 54(5), pp.1079-1097.

Association of British Insurers. 1997. Insurance Statistics Year Book: 1986-1996.

Attanasio, Orazio and Hilary Hoynes. 1995. Differential Mortality and Wealth Accumulation. NBER Working Paper 5126.

Blake, David. 1995. Pension Schemes and Pension Funds in the United Kingdom. Oxford: Clarendon Press.

Brown, Jeffrey R., Olivia S. Mitchell, and James M. Poterba. 1999. The Role of Real Annuities and Indexed Bonds in an Individual Accounts Retirement Program. National Bureau of Economic Research Working Paper \# 7005.

Brugiavini, A. 1993. Uncertainty Resolution and the Timing of Annuity Purchases. Journal of Public Economics, 50, pp.31-62.

Budd, Alan and Nigel Campbell. 1998. The roles of the public and private sectors in the U.K. pension system. In Privatizing Social Security, ed. Martin Feldstein. Chicago: University of Chicago Press.

Cawley, John and Tomas Philipson. 1999. An Empirical Examinatin of Information Barriers to Trade in Insurance. American Economic Review (forthcoming).

Friedman, Benjamin, and Mark Warshawsky. 1988. Annuity prices and saving behavior in the United States. In Z. Bodie, J. Shoven, and D. Wise, eds. Pensions in the US Economy. Chicago: University of Chicago Press.

Friedman, Benjamin, and Mark Warshawsky. 1990. The cost of annuities: Implications for saving behavior and bequests. Quarterly Journal of Economics (February), 105(1), pp.135-154.

Hamermesh, Daniel S. 1985. Expectations, Life Expectancy, and Economic Behavior. Quarterly Journal of Economics 100 (May), 389-408.

Hurd, Michael and Kathleen McGarry. 1997. The Predictive Validity of Subjective Probabilities of Survival. NBER Wokring Paper 6193.

Institute of Actuaries and Faculty of Actuaries, Continuous Mortality Investigation Committee. 1990. Continuous Mortality Investigation Reports, Number 10.

Institute of Actuaries and Faculty of Actuaries, Continuous Mortality Investigation Committee. 1999. Continuous Mortality Investigation Reports, Number 16.

Khorasanee, M. Zaki. 1996. Annuity Choices for Pensioners. Journal of Actuarial Practice, 4(2), pp.229255.

Mitchell, Olivia S., James M. Poterba, Mark Warshawsky, and Jeffrey R. Brown. 1999. New Evidence on the money's worth of individual annuities. American Economic Review (forthcoming). 
Murthi, Mamta, J. Michael Orszag, and Peter Orszag. 1999. The Charge Ratio on Individual Accounts: Lessons for the U.K. Experience. Birkbeck College, University of London Working Paper 99-2.

Poterba, James and Mark Warshawsky. 1999. The Costs of Annuitizing Retirement Payouts from Individual Accounts. NBER Working Paper 6918.

Rothschild, Michael and Joseph Stiglitz. 1976. An Essay on the Economics of Imperfect Information. Quarterly Journal of Economics, (November), 90(4), pp.629-649.

U.S. Congressional Budget Office. 1999. Social Security Privatization: Experiences Abroad. Washington: U.S. Congressional Budget Office.

Warshawsky, Mark. 1988. Private Annuity Markets in the United States. Journal of Risk and Insurance, 55, pp. 518-528.

Wilson, Charles. 1977. A Model of Insurance Markets with Incomplete Information. Journal of Economic Theory, 16, pp.167-207. 
Table 1: Expected Duration (months) of Different Annuity Products: 65-Year-Old Male Facing Population Mortality Rates

\begin{tabular}{|r|r|r|r|r|r|}
\hline Real Interest & Inflation & \multicolumn{5}{|c|}{ Expected Duration } \\
\cline { 3 - 6 } Rate & & Nominal Annuity & Real Annuity & $5 \%$ Escalating Annuity & Real-Nominal (Difference) \\
\hline 0.03 & 0.03 & 90.5 & 105.1 & 116.2 & 14.7 \\
\hline 0.03 & 0.05 & 82.4 & 105.1 & 105.1 & 22.8 \\
\hline 0.03 & 0.07 & 75.4 & 105.1 & 95.5 & 29.8 \\
\hline 0.05 & 0.03 & 82.4 & 95.3 & 105.1 & 12.9 \\
\hline 0.05 & 0.05 & 75.3 & 95.3 & 95.3 & 20.0 \\
\hline 0.05 & 0.07 & 69.1 & 95.3 & 86.8 & 26.2 \\
\hline 0.07 & 0.03 & 75.4 & 86.8 & 95.5 & 11.4 \\
\hline 0.07 & 0.05 & 69.1 & 86.8 & 86.8 & 17.6 \\
\hline 0.07 & 0.07 & 63.7 & 86.8 & 79.2 & 23.0 \\
\hline
\end{tabular}

Source: Authors' calculations based on the expected duration expression in equation (1).

Table 2: Average Annual Annuity Payments for Annuities with $£ 10,000$ Purchase Price

\begin{tabular}{|l|l|l|l||l|l|l|}
\hline & \multicolumn{2}{l||}{ Compulsory Market } & Voluntary Market \\
\hline & Nominal & Real & $5 \%$ Escalating & Nominal & Real & 5\% Escalating \\
\hline Male 65 & 879.7 & 658.6 & 550.2 & 844.4 & 636.7 & 522.9 \\
\hline Male 70 & 1036.1 & 813.0 & 703.7 & 992.8 & 780.3 & 670.4 \\
\hline Male 75 & 1252.5 & 1031.5 & 915.9 & 1198.5 & 980.3 & 871.3 \\
\hline Female 65 & 768.5 & 553.6 & 445.4 & 727.6 & 533.7 & 420.3 \\
\hline Female 70 & 885.2 & 671.1 & 560.8 & 843.5 & 650.3 & 532.1 \\
\hline Female 75 & 1056.4 & 839.2 & 727.9 & 1007.9 & 817.0 & 690.0 \\
\hline
\end{tabular}

Note: Data are provided from Moneyfacts for November 6, 1998. All products are single premium immediate annuities with no guarantee period. Compulsory annuity rates are based on a product that pays monthly in advance; voluntary annuity rates are quoted based on products that pay monthly in arrears.

Table 3: Coefficient of Variation for Monthly Payments From Annuities with $£ 10,000$ Purchase Price

\begin{tabular}{|l|l|l|l||l|l|l|}
\hline & \multicolumn{3}{|l||}{ Compulsory Market } & Voluntary Market \\
\hline & Nominal & Real & $5 \%$ Escalating & Nominal & Real & 5\% Escalating \\
\hline Male 65 & 3.11 & 6.20 & 6.92 & 2.81 & 12.91 & 6.78 \\
\hline Male 70 & 3.15 & 5.74 & 5.43 & 3.42 & 10.41 & 7.12 \\
\hline Male 75 & 3.70 & 5.84 & 5.71 & 4.31 & 8.21 & 8.04 \\
\hline Female 65 & 3.92 & 8.72 & 9.30 & 2.83 & 17.97 & 6.12 \\
\hline Female 70 & 3.83 & 7.92 & 7.43 & 3.11 & 15.51 & 6.80 \\
\hline Female 75 & 4.25 & 7.71 & 6.58 & 3.93 & 13.59 & 8.22 \\
\hline
\end{tabular}

Note: Data set is the same as that described in notes to Table 2. 
Table 4: Number of Firms Offering Different Types of Annuities in the United Kingdom

\begin{tabular}{|l|l|l|l|}
\hline Market in Which & \multicolumn{3}{|c|}{ Annuity Type } \\
\cline { 2 - 4 } Product is Offered: & Nominal & Real & $5 \%$ escalating \\
\hline Compulsory & 17 & 11 & 17 \\
\hline Voluntary & 13 & 3 & 10 \\
\hline
\end{tabular}

Notes: The 11 firms offering real annuities in the compulsory market are a subset of the 17 offering nominal or escalating annuities. The same 17 firms offer nominal and escalating compulsory products. The 13 firms offering nominal voluntary annuities are not a subset of the 17 offering nominal compulsory annuities. The 3 firms offering real voluntary annuities also offer real compulsory products and escalating voluntary annuities. The 10 firms offering escalating voluntary products are a subset of the 13 offering nominal voluntary annuities. See notes to Table 2 for a further description of the database that underlies these tabulations.

Table 5: Average Money's Worth For Various Annuities, Using U.K.Population Mortality Tables

\begin{tabular}{|l|l|l|l|||l|l|l|}
\hline & \multicolumn{2}{l||}{ Compulsory Market } & Voluntary Market \\
\hline & Nominal & Real & $5 \%$ Escalating & Nominal & Real & $5 \%$ Escalating \\
\hline Male 65 & .901 & .822 & .854 & .861 & .791 & .807 \\
\hline Male 70 & .875 & .806 & .832 & .833 & .768 & .787 \\
\hline Male 75 & .846 & .790 & .808 & .803 & .744 & .762 \\
\hline Female 65 & .902 & .817 & .844 & .851 & .785 & .793 \\
\hline Female 70 & .876 & .801 & .822 & .831 & .772 & .776 \\
\hline Female 75 & .862 & .795 & .815 & .817 & .769 & .767 \\
\hline
\end{tabular}

Note: See notes to Table 2. Money's worth calculations are based on all-sample average annuity payments and population mortality tables.

Table 6: Comparison of Money's Worth For Nominal and Escalating Annuities in Compulsory and Voluntary Market

\begin{tabular}{|l|l|l||l|l|}
\hline & \multicolumn{2}{l||}{ Nominal Annuity } & \multicolumn{3}{l|}{ 5\% Escalating Annuity } \\
\hline & Compulsory Market & Voluntary Market & Compulsory Market & Voluntary Market \\
\hline Male 65 & .897 & .865 & .858 & .804 \\
\hline Male 70 & .869 & .837 & .829 & .786 \\
\hline Male 75 & .836 & .808 & .796 & .760 \\
\hline Female 65 & .901 & .853 & .859 & .793 \\
\hline Female 70 & .873 & .833 & .828 & .776 \\
\hline Female 75 & .856 & .819 & .813 & .768 \\
\hline
\end{tabular}

Note: See notes to Table 2. Money's Worth calculations are based on population mortality tables and on average annuity payouts for the nine insurance companies that offer compulsory and voluntary nominal, and compulsory and voluntary $5 \%$ escalating, annuity products. 
Table 7: The Effect of Different Mortality Tables on the Money's Worth of Compulsory and Voluntary Annuities

\begin{tabular}{|c|c|c|c|c|c|c|}
\hline \multirow[t]{2}{*}{ Annuity Type } & \multicolumn{3}{|c|}{ Compulsory Market } & \multicolumn{3}{|c|}{ Voluntary Market } \\
\hline & $\begin{array}{l}\text { Population } \\
\text { Table }\end{array}$ & $\begin{array}{l}\text { Compulsory } \\
\text { Annuitant } \\
\text { Table }\end{array}$ & $\begin{array}{l}\text { Voluntary } \\
\text { Annuitant } \\
\text { Table }\end{array}$ & $\begin{array}{l}\text { Population } \\
\text { Table }\end{array}$ & $\begin{array}{l}\text { Compulsory } \\
\text { Annuitant } \\
\text { Table }\end{array}$ & $\begin{array}{l}\text { Voluntary } \\
\text { Annuitant } \\
\text { Table }\end{array}$ \\
\hline \multicolumn{7}{|c|}{65 Year Old Man } \\
\hline Nominal & 0.897 & 0.944 & 0.987 & 0.865 & 0.911 & 0.953 \\
\hline $5 \%$ Escalating & 0.858 & 0.922 & 0.991 & 0.804 & 0.865 & 0.930 \\
\hline \multicolumn{7}{|c|}{65 Year Old Woman } \\
\hline Nominal & 0.901 & 0.920 & 0.954 & 0.853 & 0.872 & 0.904 \\
\hline $5 \%$ Escalating & 0.859 & 0.889 & 0.940 & 0.793 & 0.822 & 0.869 \\
\hline \multicolumn{7}{|c|}{70 Year Old Man } \\
\hline Nominal & 0.869 & 0.916 & 0.984 & 0.837 & 0.883 & 0.949 \\
\hline $5 \%$ Escalating & 0.829 & 0.890 & 0.983 & 0.786 & 0.844 & 0.933 \\
\hline \multicolumn{7}{|c|}{70 Year Old Woman } \\
\hline Nominal & 0.873 & 0.891 & 0.938 & 0.833 & 0.851 & 0.896 \\
\hline $5 \%$ Escalating & 0.828 & 0.857 & 0.920 & 0.776 & 0.803 & 0.862 \\
\hline
\end{tabular}

Note: See notes to Table 2. Money's Worth calculations are based on average payments in sample of 9 firms that offer compulsory and voluntary nominal and $5 \%$ escalating products.

Table 8: Cost of Adverse Selection in Compulsory Annuity Market, as a Percentage of Cost of Adverse Selection in Voluntary Annuity Market (\%)

\begin{tabular}{|l|l|l|}
\hline & Nominal annuity & $5 \%$ escalating annuity \\
\hline 65 year old man & $53.4 \%$ & $50.8 \%$ \\
\hline 65 year old woman & 37.3 & 39.5 \\
\hline 70 year old man & 42.0 & 41.5 \\
\hline 70 year old woman & 28.6 & 33.7 \\
\hline
\end{tabular}

Notes: Each entry corresponds to ( $\mathrm{MW}_{\text {compulsory annuitant table, compulsory market }}-\mathrm{MW}_{\text {population mortality table, compulsory market }}$ )/ $\left(\mathrm{MW}_{\text {voluntary annuitant table, voluntary market }}-\mathrm{MW}_{\text {population mortality table, voluntary market }}\right)$. The money's worth calculations that underlie these calculations are reported in columns 1,2, 4, and 6 of Table 7. 
Table 9: Share of Deviation Between Actual Money's Worth and 1.0 ("Actuarial Fairness") That Is Attributable to Adverse Selection

\begin{tabular}{|l|l|l|}
\hline Annuity Buyer and Product Type & Compulsory market & $\begin{array}{l}\text { Voluntary } \\
\text { Market }\end{array}$ \\
\hline 65 year old man, nominal annuity & 45.6 & 65.2 \\
\hline 65 year old man, 5\% escalating annuity & 45.1 & 64.3 \\
\hline 65 year old woman, nominal annuity & 19.2 & 34.7 \\
\hline 65 year old women, 5\% escalating annuity & 21.3 & 36.7 \\
\hline 70 year old man, nominal annuity & 35.9 & 68.7 \\
\hline 70 year old man, 5\% escalating annuity & 35.7 & 68.7 \\
\hline 70 year old woman, nominal annuity & 14.2 & 37.7 \\
\hline 70 year old women, 5\% escalating annuity & 16.9 & 38.4 \\
\hline
\end{tabular}

Note: Entries for the compulsory annuity market report the value of $100 *\left(\mathrm{MW}_{\text {compulsory annuitant table }}\right.$ $\left.\mathrm{MW}_{\text {population mortality table }}\right) /\left(1-\mathrm{MW}_{\text {population mortality table }}\right)$, where the policies analyzed are those in the voluntary annuity marketplace. The denominator is the effective "load factor" on compulsory annuities, computed with reference to the population mortality table. For the voluntary market, the entries are $100^{*}(1-$ $\left.\mathrm{MW}_{\text {voluntary annuitant table }}\right) /\left(1-\mathrm{MW}_{\text {population mortality table }}\right)$, where the policies analyzed are those in the voluntary annuity marketplace. Entries for the money's worth values are found in Table 7.

Table 10: Comparison of Money's Worth Values Across Product Types in the Compulsory Annuity Market

\begin{tabular}{|l|l|l|l|}
\hline & Nominal Annuity & Real Annuity & 5\% Escalating Annuity \\
\hline Male 65 & .897 & .822 & .856 \\
\hline Male 70 & .874 & .805 & .836 \\
\hline Male 75 & .851 & .790 & .818 \\
\hline Female 65 & .900 & .817 & .851 \\
\hline Female 70 & .877 & .801 & .829 \\
\hline Female 75 & .865 & .795 & .823 \\
\hline
\end{tabular}

Note: See notes to Table 2. Money's worth calculations are based on population mortality tables and on average payments in sample of 11 firms that offer nominal, real and 5\% escalating compulsory products. 
Table 11: Comparison of Money's Worth Values for Different Annuity Products Available in the Voluntary and Compulsory Annuity Market

\begin{tabular}{|l|l|l|l||l|l|l|}
\hline Annuity Market & \multicolumn{4}{l||}{ Compulsory } & \multicolumn{2}{l|}{ Voluntary } \\
\hline Annuity Product & Nominal & Real & 5\% Escalating & Nominal & Real & 5\% Escalating \\
\hline Male 65 & 0.892 & 0.781 & 0.849 & 0.865 & 0.791 & 0.807 \\
\hline Male 70 & 0.870 & 0.770 & 0.828 & 0.836 & 0.768 & 0.786 \\
\hline Male 75 & 0.845 & 0.750 & 0.807 & 0.804 & 0.744 & 0.759 \\
\hline Female 65 & 0.879 & 0.754 & 0.820 & 0.864 & 0.785 & 0.809 \\
\hline Female 70 & 0.854 & 0.745 & 0.797 & 0.844 & 0.772 & 0.793 \\
\hline Female 75 & 0.839 & 0.738 & 0.786 & 0.833 & 0.769 & 0.787 \\
\hline
\end{tabular}

Note: See notes to Table 2. Money's worth calculations are based on population mortality tables and on average payments for the three firms that offer nominal, real and 5\% escalating compulsory and voluntary products.

Table 12: Money's Worth Calculations for Annuity Policies with Different Initial Premium Amounts, U.K. Compulsory Annuity Market, 1998

\begin{tabular}{|l|l|l|l|}
\hline Premium Amount & $£ 10,000$ & $£ 50,000$ & $£ 100,000$ \\
\hline Male 60 & 0.907 & 0.922 & 0.921 \\
\hline Male 65 & 0.897 & 0.910 & 0.908 \\
\hline Male 70 & 0.886 & 0.892 & 0.889 \\
\hline Female 60 & 0.914 & 0.930 & 0.928 \\
\hline Female 65 & 0.898 & 0.912 & 0.907 \\
\hline Female 70 & 0.882 & 0.892 & 0.886 \\
\hline
\end{tabular}

Note: Data are provided by Annuity Direct for August 21, 1998. All products are nominal annuities with a five year guarantee period. Products are paid monthly in arrears. Calculations are based on average annuity payouts for the fourteen firms in the sample, and are based on population mortality tables. 
Appendix Table A1: Cohort and Period Mortality Tables, Different Population Groups

\begin{tabular}{|c|c|c|c|c|c|}
\hline \multirow[t]{2}{*}{ Age } & \multicolumn{3}{|c|}{ Cohort Mortality Table, 65 Year Old Males, 1998} & \multicolumn{2}{|l|}{ Period Mortality Table } \\
\hline & Population & $\begin{array}{l}\text { Voluntary } \\
\text { Annuitant }\end{array}$ & $\begin{array}{l}\text { Compulsory } \\
\text { Annuitant }\end{array}$ & $\begin{array}{l}\text { Compulsory Annuitants, } \\
1991-94\end{array}$ & $\begin{array}{l}\text { Voluntary } \\
\text { Annuitants, 1979-1982 }\end{array}$ \\
\hline 65 & 0.021155 & 0.016112 & 0.015994 & 0.01812 & 0.022903 \\
\hline 66 & 0.023042 & 0.01743 & 0.017674 & 0.0204 & 0.024947 \\
\hline 67 & 0.024879 & 0.018682 & 0.019386 & 0.022923 & 0.027172 \\
\hline 68 & 0.026835 & 0.019998 & 0.021327 & 0.025708 & 0.029591 \\
\hline 69 & 0.029325 & 0.021699 & 0.023765 & 0.028775 & 0.032223 \\
\hline 70 & 0.032042 & 0.023542 & 0.026504 & 0.032142 & 0.035084 \\
\hline 71 & 0.034666 & 0.025276 & 0.02913 & 0.035831 & 0.038195 \\
\hline 72 & 0.037762 & 0.027343 & 0.032058 & 0.039862 & 0.041575 \\
\hline 73 & 0.041097 & 0.029572 & 0.035225 & 0.044253 & 0.045247 \\
\hline 74 & 0.044811 & 0.03207 & 0.038926 & 0.049025 & 0.049235 \\
\hline 75 & 0.049401 & 0.035211 & 0.043491 & 0.054197 & 0.053565 \\
\hline 76 & 0.054166 & 0.03849 & 0.048043 & 0.059787 & 0.058264 \\
\hline 77 & 0.059154 & 0.041939 & 0.052753 & 0.065811 & 0.063361 \\
\hline 78 & 0.064793 & 0.045896 & 0.058076 & 0.072286 & 0.068887 \\
\hline 79 & 0.071073 & 0.050377 & 0.063938 & 0.079225 & 0.074876 \\
\hline 80 & 0.07814 & 0.055502 & 0.07056 & 0.086639 & 0.081362 \\
\hline 81 & 0.086192 & 0.061448 & 0.078262 & 0.094538 & 0.088383 \\
\hline 82 & 0.094732 & 0.067868 & 0.086302 & 0.102929 & 0.095977 \\
\hline 83 & 0.103326 & 0.074472 & 0.09424 & 0.111815 & 0.104186 \\
\hline 84 & 0.111677 & 0.081073 & 0.10191 & 0.121196 & 0.113052 \\
\hline 85 & 0.119542 & 0.08755 & 0.109194 & 0.131071 & 0.12262 \\
\hline 86 & 0.127938 & 0.094773 & 0.116596 & 0.141431 & 0.132935 \\
\hline 87 & 0.137994 & 0.103741 & 0.125357 & 0.152267 & 0.144044 \\
\hline 88 & 0.149183 & 0.114162 & 0.135675 & 0.163563 & 0.155995 \\
\hline 89 & 0.159993 & 0.124953 & 0.146186 & 0.175302 & 0.168837 \\
\hline 90 & 0.170493 & 0.136229 & 0.15656 & 0.18746 & 0.182617 \\
\hline 91 & 0.182774 & 0.149875 & 0.167141 & 0.200011 & 0.197383 \\
\hline 92 & 0.196675 & 0.165968 & 0.177277 & 0.212925 & 0.21318 \\
\hline 93 & 0.209681 & 0.182327 & 0.186018 & 0.226167 & 0.23005 \\
\hline 94 & 0.222162 & 0.198978 & 0.194662 & 0.2397 & 0.248034 \\
\hline 95 & 0.23538 & 0.216779 & 0.204548 & 0.253482 & 0.267166 \\
\hline 96 & 0.249194 & 0.235337 & 0.215129 & 0.267471 & 0.287472 \\
\hline 97 & 0.263455 & 0.25413 & 0.226032 & 0.28162 & 0.308974 \\
\hline 98 & 0.278061 & 0.272809 & 0.236821 & 0.29588 & 0.33168 \\
\hline 99 & 0.295053 & 0.293098 & 0.249192 & 0.310203 & 0.35559 \\
\hline 100 & 0.313999 & 0.314696 & 0.262172 & 0.324539 & 0.380688 \\
\hline 101 & 0.336639 & 0.33889 & 0.277923 & 0.338835 & 0.406942 \\
\hline 102 & 0.36192 & 0.364482 & 0.295743 & 0.353042 & 0.434302 \\
\hline 103 & 0.390875 & 0.393834 & 0.313931 & 0.367107 & 0.4627 \\
\hline 104 & 0.419028 & 0.423155 & 0.326794 & 0.380983 & 0.492042 \\
\hline 105 & 0.452962 & 0.454147 & 0.351919 & 0.394621 & 0.522214 \\
\hline 106 & 0.484076 & 0.483076 & 0.373082 & 0.407973 & 0.553075 \\
\hline 107 & 0.530864 & 0.521963 & 0.418178 & 0.420997 & 0.584458 \\
\hline 108 & 0.552632 & 0.565889 & 0.392573 & 0.433649 & 0.616173 \\
\hline 109 & 0.647059 & 0.419295 & 0.457599 & 0.44589 & 0.648002 \\
\hline
\end{tabular}




\begin{tabular}{|l|r|r|r|r|r|}
\hline 110 & 0.666667 & 0.453139 & 0.305123 & 0.457684 & 0.679708 \\
111 & 0.5 & 0.355518 & 0.234499 & 0.468997 & 0.711035 \\
112 & 1 & 0.741713 & 0.479798 & 0.479798 & 0.741713 \\
113 & 1 & 0.771464 & 0.49006 & 0.49006 & 0.771464 \\
114 & 1 & 0.800013 & 0.499756 & 0.499756 & 0.800013 \\
115 & 1 & 0.827094 & 0.508865 & 0.508865 & 0.827094 \\
\hline
\end{tabular}

Note: All columns report conditional death probabilities. The first three columns present the mortality tables that are used to compute money's worth values for 65 year old males. Column 5 gives the "raw" compulsory annuitant mortality table from which Column 4 was derived. Column 6 gives the "raw" voluntary annuitant mortality table from which Column 3 was derived. See the text for a description of how Columns 5 and 6 were transformed into Columns 4 and 3. 